\title{
OPTIMIZATION OF ENERGY SAVINGS IN SHOE SOLE PRODUCTION
}

\author{
Ivana Špelić1, Alka Mihelić-Bogdanić1, Rajka Budin² \\ ${ }^{1 *}$ University of Zagreb, Faculty of Textile Technology, Prilaz baruna Filipovića 28a, 10000 Zagreb, \\ Croatia
}

E-mail: ispelic@ttf.hr; amihelic@ttf.hr

${ }^{2}$ University of Zagreb, Faculty of Chemical Engineering and Technology, Marulićev trg 19, 10000 Zagreb, Croatia

E-mail: rbudin@fkit.hr

Original Scientific Paper

UDK: 66.011/.012:685.34.024.5

\begin{abstract}
Since 1970's, the most popular shoe soles are (EVA) soles, made from Ethylene Vinyl Acetate, copolymer consisting of ethylene and vinyl acetate. The thermosets and elastomers (rubbers), among them accounting EVA, encompasses around $30 \%$ of the tonnage of all synthetic polymers produced, with the synthetic rubbers exceeding the tonnage of natural rubber. With that in mind, the energy savings in rubber processing plants are of great importance and the paper analyses the potential of energy savings in shoe soles production process made of Ethylene Vinyl Acetate (EVA). The shoe soles made from EVA are lightweight, easy to mould, water and moisture resistant, highly elastic, shock absorbent, great thermal insulators, highly durable, etc.

The energy savings using the process return condensate in shoe sole production process are presented. Using the return condensate results in lower make up water consumption, substantial fuel savings needed to produce steam and lower chemical consumption. Returning hot process condensate to the boiler results in oil savings of $14,9 \%$. Also, the thermal pollution is reduced by $95,3 \%$, while the volume of the flue gases is lowered from $17,11 \mathrm{~m}_{\mathrm{FG}}^{3} / \mathrm{kg}_{\mathrm{NEC}}$ to $14,57 \mathrm{~m}_{\mathrm{FG}}^{3} / \mathrm{kg}_{\mathrm{NEC}}$ or by $14,8 \%$. Such a system enables both the oil savings and reduces the thermal pollution.

The comparison of process with and without flue gases heat recovery shows fuel savings of $18,76 \%$, while the temperature reduces from $221^{\circ} \mathrm{C}$ to $137,39^{\circ} \mathrm{C}$ and while the volume of the flue gases is lowered to $13,90 \mathrm{~m}^{3}{ }_{\mathrm{FG}} / \mathrm{kg}_{\mathrm{P}}$.
\end{abstract}

\section{Ključne riječi}

energy savings; return condensate; shoe sole production, Ethylene Vinyl Acetate (EVA), thermal pollution reduction.

\section{INTRODUCTION}

The last century was marked by appearance of new plastic foams, among others new thermosetting foams were introduced to the global market. Thermosetting foams, among which there are also natural and synthetic rubbers, are defined for not having thermosplastic properties and are prepared by simultaneous occurance of polymer formation and gas generation. As a general rule, any polymer-forming reaction can be used for foam preparation. First rubber production began in World War I as natural or raw rubber products were introduced (Landrock, 1995). Engineering materials are classified as metals, ceramics, polymers and composites. Polymers are further classified as thermoplastics, thermosets and elastomers. Thermoplastic polymers can be subjected to multiple heating and cooling cycles without substantially altering the molecular structure of the polymer. Common thermoplastics include polyethylene, polystyrene, polyvinylchloride, and nylon (Groover, 2010).

There are several industries involved in the production and processing of rubber, but today most of the rubber used is classified as synthetic rubber, which is produced by the petrochemical industry in processor (fabricator) plants. Many foamed rubber parts, such as shoe soles, are produced by molding. Products formulated from thermoplastic polymers, which include ethylene vinyl acetate, polyethylene, styrene block copolymer, butyl rubber, polyamide, polyurethane, and polyester, can be prepared as hot melt. Singlecomponent thermoplastic hardens from molten state after cooling from elevated temperatures (Groover, 2010).

The shoe soles or outsoles are the bottom part of the shoes in direct contact with the floor. Nowadays they are usually made from synthetic polymers such as Polyisoprene (IR), Thermoplastic Polyurethane (TPU), Polyurethane foams, Ethylene Vinyl Acetate (EVA) or Polyvinylchloride (PVC). Synthetic polymers are made from various petroleum-based monomers and the polymers have become the main specialized materials for footwear industry (Karkalića et al., 2017). 
Since the creation in 1970's, the most popular soles are Ethylene Vinyl Acetate (EVA) soles (Wang et al., 2012; Fuss et al., 2014). A large range of articles using EVA are being produced for the footwear industry (Lopes et al, 2015). Ethylene Vinyl Acetate is polymer based copolymer consisting of ethylene and vinyl acetate (Shi et al., 2008; Brito e Dias et al., 2018), also called expanded rubber or foam rubber, Figure 1. It is a polyolefin with the ethylene weight percentage varying from $60-90 \%$ (Mike Chung, 2002), while the vinyl acetate weight percentage usually varies from 10 to 40\% (Nautiyal, 2012).

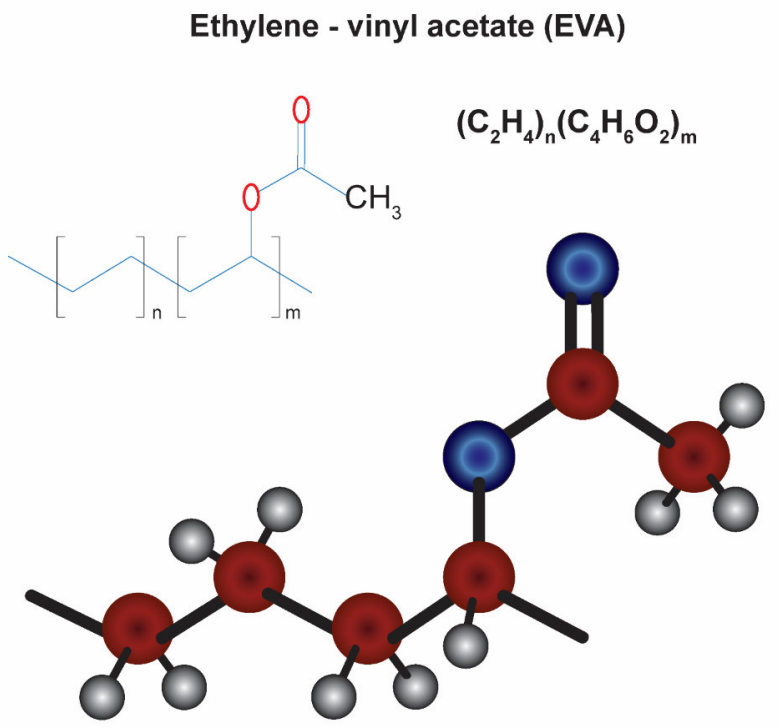

Figure 1. The structural formula of Ethylene Vinyl Acetate (EVA)

The Ethylene Vinyl Acetate can be injected like other polyolefin elastomers (new class of polymers, mostly copolymers of ethylene-butene or ethylene-octen, produced using metallocen catalyst) (Mike Chung, 2002). This EVA material has good clarity, low temperature toughness, stress-crack resistance, hotmelt adhesive water proof properties, and resistance to UV radiation, similar softness, extreme elasticity and flexibility of elastomeric material, but it can also be processed like other thermoplastic materials (Mike Chung, 2002; Wang et al., 2012; Nautiyal, 2012). The main characteristics of EVA is considerable elasticity characterized by the Young Modulus ranging from 15 to $80 \mathrm{MPa}$ (Brito e Dias et al., 2018).

EVA is also known as expanded rubber or foam rubber. The material is known to be lightweight and easy to mould, but also owns its' popularity to cheaper price when compared to natural rubber. Other popular properties involve good water and moisture resistance, high elasticity, great shock absorption, great thermal insulation properties, durability, low-temperature toughness, stress-crack resistance, hot-melt adhesive water proof properties and resistance to UV radiation (Jeng et al., 2012). Soles made from Ethylene vinyl acetate (EVA) are known for their softness and flexibility. Figure 2. They are processed like other thermoplastics materials. EVA has little or no odour and is competitive with rubber and vinyl products in many electrical applications (Nautiyal, 2012).

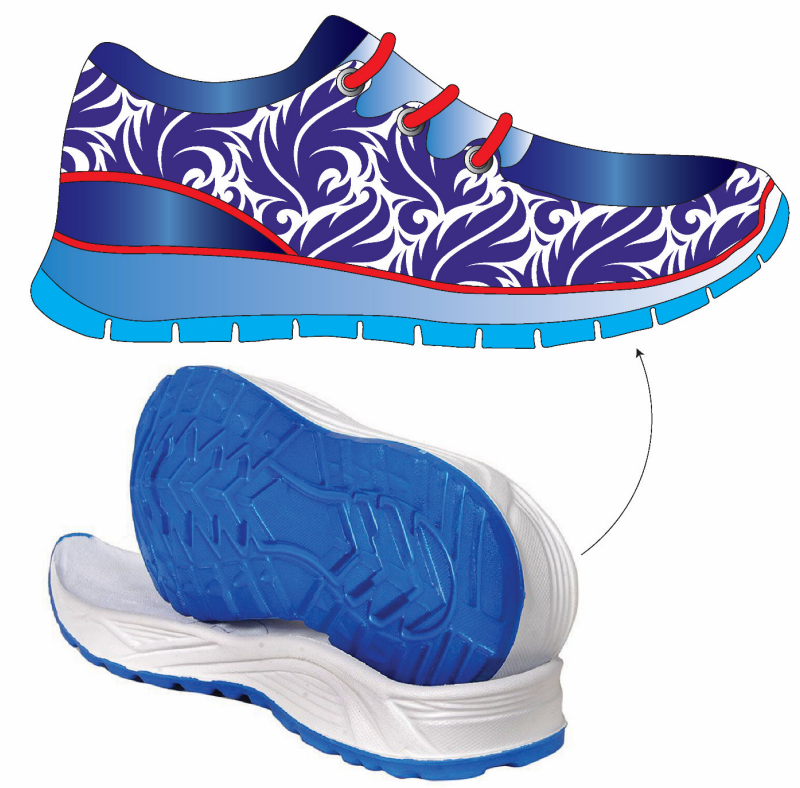

Figure 2. The EVA shoe soles for sneakers

\subsection{SHOE SOLES INJECTION MOLDING PROCESS}

Principal molding processes for rubber are (Groover, 2010):

1. compression molding,

2. transfer molding, and

3. injection molding.

There are two basic ways to mold the EVA soles. First one is the compression molded EVA (CMEVA) is made by filling a mold with EVA pellets to achieve desired shape or by compressing a block of EVA foam inside a metal mold. The heat and pressure are applied to the mold, causing the pellets to melt or causing the EVA foam to expand and fill the mold cavity. The second one is the injection molding process. Direct injection is the process of forcing a heated thermoplastics polymer of a highly plastic state under high pressure into the cavity of a mold to achieve desired shape. The process produces discrete components that are almost always net shape. The production cycle time is typically in the range of 10 to $30 \mathrm{sec}$ (Groover, 2010). When the material solidifies in the mold it takes the desired shape and is removed from the mold. The injection molding is quite popular due to zero wastage as the exact amount of EVA is required. A single cavity or multiple cavities moulds are generally made of tools steal, aluminium or stainless steel (López, 2014). The injection molding is economical only for large production quantities. With injection molding of rubber, there are risks of premature curing. Advantages of injection molding include better dimensional control, less scrap and shorter cycle times. Because of high mold costs, large production quantities 
are required to justify injection molding (Groover, 2010).

An injection molding machine consists of, Figure 3 :

1. the plastic injection unit (similar to the extruder) and

2. the mold clamping unit (power press).

The plastic injection unit consists of a barrel that is fed by a hopper containing a supply of plastic pellets. Inside the barrel is a reciprocating unit, which turns and heats the polymer, and also injects the molten plastic into the mold. The mold clamping unit holds the two platens, affixed and a moveable platen, in proper alignment with each other, and keeps the mold closed during injection by applying a clamping force sufficient to resist the injection force and opens and close the mold (Groover, 2010).

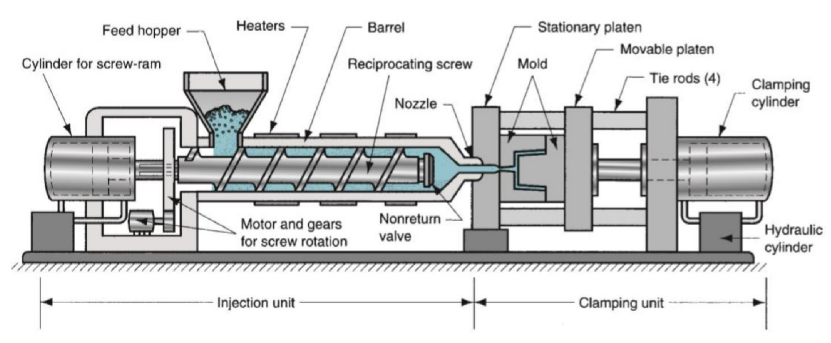

Figure 3. The injection molding machine

The EVA mixed compound is taken to an injector that can be rotating or multi-station since the average injection cycle of each mold is around 7 minutes, so with a multi-station machine you can achieve a faster and more efficient production (Ferreir et al., 2018).

The steps of the EVA injection process (Ferreir et al., 2018):

(a) The mixture is added to the injector storage tank.

(b) The injection volume is calculated and adjusted according to the mold.

(c) The material is heated to $95^{\circ} \mathrm{C}$ and injected into the mold at a pressure of $\sim 1200$ bar.

(d) The mold is heated to $170{ }^{\circ} \mathrm{C}$ to activate the expander and also the crosslinking agents

(e) The mold is kept closed at $170{ }^{\circ} \mathrm{C}$ until the crosslinks are fully completed, about $1.5 \mathrm{~min} / \mathrm{mm}$ thick

(f) The mold is opened, and the EVA sole jumps out of the cavity rapidly and begins to expand.

The technical description for the selected Automatic Eva Foam Injection Molding Machine and the yearly energy analysis is shown in Table 1.
Table 1. The Technical Description for Automatic Eva Foam Injection Molding Machine

\begin{tabular}{|c|c|}
\hline \multicolumn{2}{|c|}{ Technical Description } \\
\hline Work Stations & 6 \\
\hline Clamping Force $(\mathrm{kg})$ & $170000-230000$ \\
\hline Mould-Opening Stroke (mm) & 350 \\
\hline Standard Thickness of Mould $(\mathrm{mm})$ & $100-210-230$ \\
\hline Mould Plate Size (mm) & $2(290 * 550)$ \\
\hline Height of Injection Nozzle (mm) & 60 \\
\hline Method of Heating & electric \\
\hline Heating Power (kw) & 8.04 \\
\hline \multicolumn{2}{|l|}{ Injection System } \\
\hline Injectors (set) & 2 \\
\hline Diameter of Screw (mm) & $60 / 70$ \\
\hline L/D Ratio of Screw & 23 \\
\hline Max Injection Capacity (cc) & $920-1100$ \\
\hline Injection Pressure & 1100 \\
\hline Injection Speed (cm/sec) & 10 \\
\hline Rotating Speed of Screw (r.p.m) & $0-190$ \\
\hline Temperature Control (section) & 4 \\
\hline \multicolumn{2}{|l|}{ Electricity Consumption } \\
\hline Heater Barrel (kw) & 12.1 \\
\hline Motor for Injector Moving (kw) & 1.5 \\
\hline Heating Board of Mould (kw) & 76.8 \\
\hline Hydraulic System (kw)(50hz) & 40.5 \\
\hline Vacuum Pump (kw) & 2.2 \\
\hline Cooling Fan of Barrel (HP) & 1 \\
\hline Total Electricity (kw) & $50 / 70 / 150$ \\
\hline Oil Tank Size (L) & 1000 \\
\hline Machine Weight (kg) & 23800 \\
\hline Machine size $(\mathrm{m})$ & $6.5^{\star} 4.5^{\star} 2.8$ \\
\hline Output (Pairs/day) & 5000 \\
\hline Working times (h/day) & 8 \\
\hline Monthly working times (days/month) & 25 \\
\hline
\end{tabular}

\subsection{INPUT DATA AND ENERGY ANALYSIS OF TECHNOLOGICAL PROCESS}

The energy consumption in shoe sole process manufacturing at rate $\mathrm{n}=2500$ per shift (or 5000 pairs per day or 625 pairs per hour), is carried out. This technology (Fig. 2) includes processes in mixer, warming mill, calender, cutter, extruder, cooler etc. The plant works 8 hours in day, 25 days in month or $\mathrm{T}=2400$ hours yearly, i.e. so the plant use factor becomes $\beta=27$, $4 \%$. Such a basic process needs electrical energy in amount of $e_{\mathrm{e}}=3,44 \mathrm{kWh} \mathrm{n} / \mathrm{kg}$ product and dry saturated steam (13 bar) in mass of $d_{s}=14,870 \mathrm{~kg}_{s} / \mathrm{kg}$ product. The process uses also water in mass of $d_{w}=4,57 \mathrm{~kg}_{w} / \mathrm{kg}$ product (Mihelić-Bogdanić i Budin, 2008). Dry saturated steam is produced in an oil fuelled boiler with efficiency $\eta_{B}=80 \%$. 


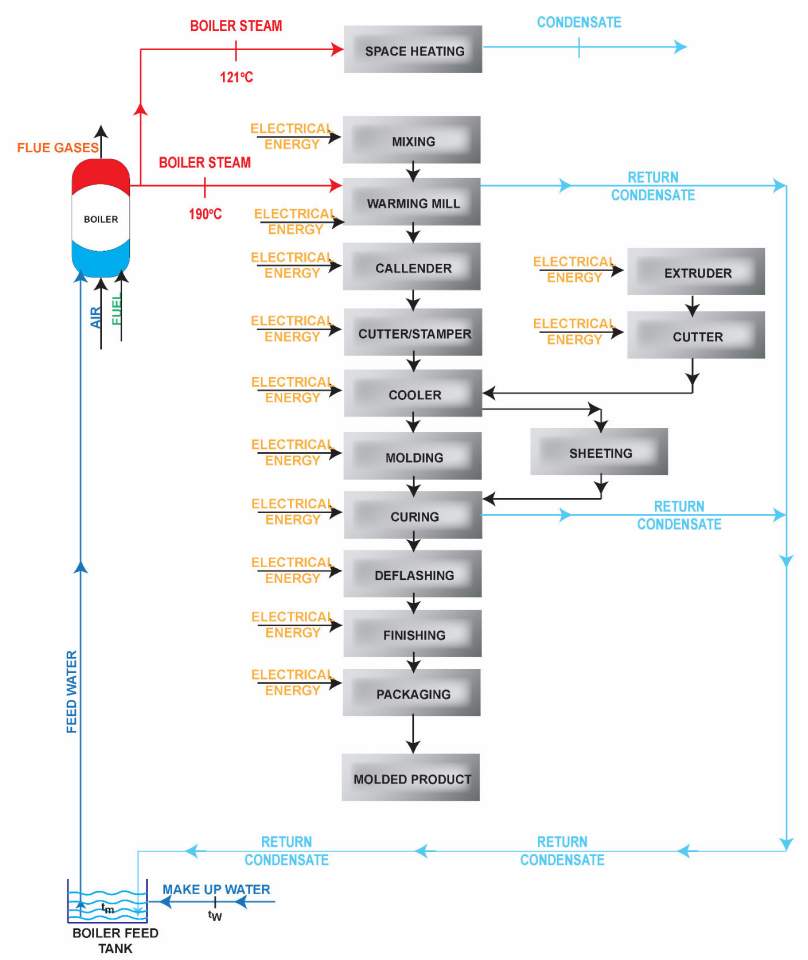

Figure 4. Shoe sole process flow diagram

The percentage composition of oil by mass is: C:H:N:S $=85,3 \%: 11,6 \%: 0,6 \%: 2,5 \%$ and is burned with excess air coefficient $\alpha=1,25$. A part of saturated steam $d_{S P}=14,170 \mathrm{~kg}_{S} / \mathrm{kg}_{\mathrm{P}}$ is used for industrial process and the rest $d_{S H}=0,7 \mathrm{~kg}_{S} / \mathrm{kg}_{H}$ for space heating. The lower heating value of oil is $\mathrm{H}_{\mathrm{L}}=41268 \mathrm{~kJ} / \mathrm{kg}$ (MihelićBogdanić i Budin, 2008). Feed water enters the boiler with temperature $t_{B}=25^{\circ} \mathrm{C}$ and the whole condensate with temperature $t_{c}=121^{\circ} \mathrm{C}$ is withdrawn to the to the surrounding. The air required for oil combustion passes into firebox with temperature $t_{a}=25^{\circ} \mathrm{C}$, while the temperature of exhaust stacks is $t_{\mathrm{FG}}=221^{\circ} \mathrm{C}$.

The heat transferred to the steam generator is: $\mathrm{q}_{\mathrm{s}}=\mathrm{d}_{\mathrm{s}}\left(\mathrm{h}_{\mathrm{s}}-\mathrm{h}_{\mathrm{B}}\right)=14,870(2785-104,68)=39856,36 \mathrm{~kJ} / \mathrm{kg}_{\mathrm{p}}$, where $h_{S}$ and $h_{B}$ are the steam and water enthalpies taken from thermodynamically tables (Mihelić Bogdanić and Budin, 2008).

From this data the unit mass of oil requirement using heat balance is:

$$
d_{F}=q_{S} / H_{L} \times \eta_{B}=39856,36 / 41268 \times 0,80=1,21 \mathrm{~kg}_{F} / k_{P} \text {. }
$$

The specific steam consumption is:

$$
d_{S P}=d_{S} / d_{F}=14,870 / 1,21=k_{S} / k_{F} \text {, }
$$

or the oil consumption becomes:

$$
d_{S F}=d_{F} / d_{s}=1,21 / 14,870=0,0814 \mathrm{~kg}_{\mathrm{F}} / \mathrm{kg}_{\mathrm{S}} \text {. }
$$

Taking into consideration yearly operating time $\mathrm{T}=2400$ hours and shoe sole rate $n=625$ pairs, oil consumption is:

$$
D_{F Y}=d_{F} \times T \times n=1,21 \times 2400 \times 625=1,815 \times 10^{6} \mathrm{~kg}_{\mathrm{F}} .
$$

The total condensate $d_{C}$ from the process $d_{C P}=14,170$ $\mathrm{kg}_{\mathrm{C}} / \mathrm{kg}_{\mathrm{P}}$ and from the space heating $\mathrm{d}_{\mathrm{CH}}=0,7 \mathrm{~kg}_{\mathrm{C}} / \mathrm{kg}_{\mathrm{H}}$ with temperature $t_{c}=121^{\circ} \mathrm{C}$ is withdrawn to the surrounding (Fig. 3).

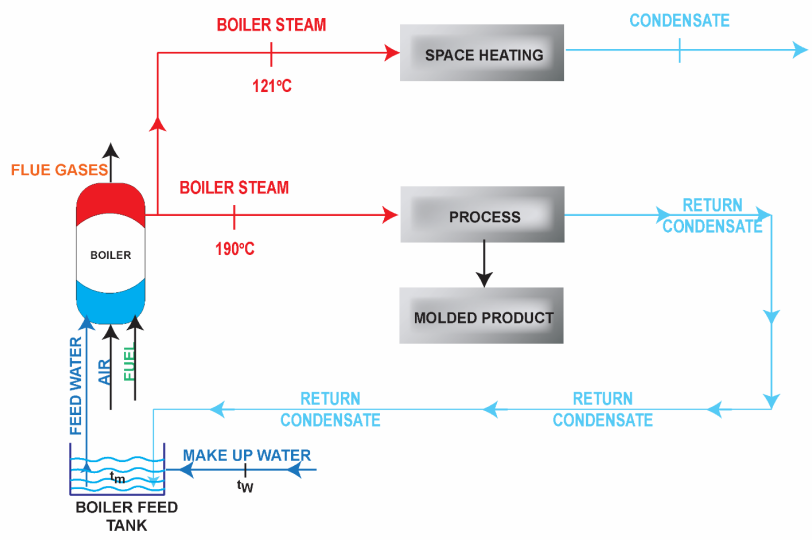

Figure 5. Returning hot process condensate

The heat of the condensate is:

$\mathrm{q}_{\mathrm{C}}=\left(\mathrm{d}_{\mathrm{CP}}+\mathrm{d}_{\mathrm{CH}}\right) \mathrm{h}_{121}=(14,170+0,7) 507=7539,1 \mathrm{~kJ}_{\mathrm{C}} / \mathrm{kg}_{\mathrm{P}}$ To improve process efficiency [9], the waste condensate could be applicate for feed water preheating.

\section{ANALYSES OF COMBUSTION PRODUCTS}

The products of fuel combustion are mostly gaseous (Eastop and McConkey, 1994). For complete oil combustion, $25 \%$ air is supplied. The minimum oxygen volume $\mathrm{V}_{\mathrm{O} 2 \text { min }}$ and stehiometric air volume $\mathrm{V}_{\mathrm{a}}$ required for combustion is expressed as:

$$
\begin{gathered}
\mathrm{V}_{\mathrm{O} 2 \min }=(22,4 / 12)\{\mathrm{C}+3[\mathrm{H}-(\mathrm{O}-\mathrm{s}) / 8]\}=2,26 \mathrm{~m}^{3}{ }_{02} / \mathrm{kg}_{\mathrm{F}} \\
\mathrm{V}_{\mathrm{a}}=\mathrm{V}_{\mathrm{O} 2 \min } / 0,21=10,8 \mathrm{~m}^{3} \mathrm{a} / \mathrm{kg}_{\mathrm{F}}
\end{gathered}
$$

To make safe the complete combustion of oil the excess coefficient of $\alpha=1,25$ was taken.

The actual volume of air is:

$$
V_{a \alpha}=V_{a} \times \alpha=10,8 \times 1,25=13,5 \mathrm{~m}^{3} / \mathrm{kg}_{\mathrm{F}} \text {. }
$$

The total volume of wet flue gases $V_{F G}$ consists of carbon dioxide, sulphur dioxide, nitrogen, excess oxygen and water vapour:

$$
\mathrm{V}_{\mathrm{FG}}=\mathrm{V}_{\mathrm{CO} 2}+\mathrm{V}_{\mathrm{SO} 2}+\mathrm{V}_{\mathrm{N} 2}+\mathrm{V}_{\mathrm{O} 2}+\mathrm{V}_{\mathrm{H} 2 \mathrm{O}}
$$

Volume of each gas component is calculated using following expressions:

$$
\begin{aligned}
& \mathrm{V}_{\mathrm{CO} 2}=\left(22,4 / 12 \mathrm{C}=(22,4 / 12) 0,853=1,592 \mathrm{~m}^{3} \mathrm{CO} / \mathrm{kg}_{\mathrm{F}}\right. \\
& \mathrm{V}_{\mathrm{SO} 2}=(22,4 / 32) \mathrm{S}=(22,4 / 32) 0,025=0,0175 \mathrm{~m}^{3} \mathrm{SO}_{2} / \mathrm{kg}_{\mathrm{F}} \\
& \mathrm{V}_{\mathrm{N} 2}=(22,4 / 28) \mathrm{S}+0,79 \times \mathrm{V}_{\mathrm{aa}}=(22,4 / 28) 0,006+0,79 \times 13,5= \\
& 10,67 \mathrm{~m}^{3}{ }_{\mathrm{N} 2} / \mathrm{kg}_{\mathrm{F}} \\
& \mathrm{V}_{\mathrm{O} 2}=0,21(\alpha-1) \mathrm{V}_{\mathrm{a}}=0,21(1,25-1) 10,8=0,567 \mathrm{~m}^{3}{ }_{\mathrm{O} 2} / \mathrm{kg}_{\mathrm{F}} \\
& \left.\mathrm{V}_{\mathrm{H} 2 \mathrm{O}}=(22,4 / 2) \mathrm{H}\right) \\
& +(22,4 / 18) \mathrm{W}=(22,4 / 2) 0,116+(22,4 / 18) 0=1,299 \\
& \mathrm{~m}^{3}{ }_{\mathrm{H} 2 \mathrm{O}} / \mathbf{k g}_{\mathrm{F}}
\end{aligned}
$$


and the whole volume of exhaust gases with excess air is:

$$
V_{F G}=14,1455 \mathrm{~m}^{3}{ }_{\mathrm{FG}} / \mathrm{kg}_{\mathrm{F}}
$$

The proportional of each constituent expressed as a percentage of the total wet product is:

$\mathrm{CO}_{2}$ : $11,25 \%$; $\mathrm{SO}_{2}: 0,12 \% ; \mathrm{N}_{2}: 75,43 \% ; \mathrm{O}_{2}: 4,02 \%$;

$$
\mathrm{H}_{2} \mathrm{O}: 9,18 \% \text {. }
$$

The specific heat of exhaust gases with temperature $t_{F G}=221^{\circ} \mathrm{C}$ and the percentage by volume of products as well as the specific heat of each gas, should be obtained (Bošnjaković, 1971):

$$
\begin{aligned}
& \mathrm{c}_{\mathrm{p} \mathrm{FG}}=\mathrm{c}_{\mathrm{p} \mathrm{CO2}} \mathrm{c} \% \mathrm{~V}_{\mathrm{CO} 2}+\mathrm{c}_{\mathrm{p} \mathrm{SO} 2} \times \% \mathrm{~V}_{\mathrm{SO} 2}+\mathrm{c}_{\mathrm{p} \mathrm{N} 2} \times \% \mathrm{~V}_{\mathrm{N} 2}+\mathrm{c}_{\mathrm{p}} \\
& { }_{02} \times \% V_{2}+c_{p ~ H 2 O} \times \% V_{\mathrm{H} 2 \mathrm{O}}=1,392 \mathrm{~kJ} / \mathrm{m}^{3} \text { grad. }
\end{aligned}
$$

The energy released on the complete combustion per unit mass of the fuel or per unit of products depends on total flue gases volume, specific heat and flue gases temperature:

$$
\begin{gathered}
q_{F G}=V_{F G} \times C_{p F G} \times t_{F G}=\begin{array}{c}
14,1455 \times 1,392 \times 221=4351,61 \\
k J_{F G} / k_{F F}
\end{array} \\
q_{F G P}=q_{F G} \times d_{F}=4351,61 \times 1,21=5265 \mathrm{~kJ}_{F G} / k_{P .} .
\end{gathered}
$$

The volume of exhaust gases per unit of product rejected to the surrounding with temperature $t_{F G}=221^{\circ} \mathrm{C}$ is:

$$
V_{F G}=V_{F G} \times d_{F}=14,1455 \times 1,21=17,11 \mathrm{~m}^{3}{ }_{F G} / k_{P}
$$

\section{OPTIMIZATION OF ENERGY SAVINGS IN SHOE SOLE PRODUCTION}

\subsection{PROCESS CONDENSATE HEAT RECOVERY}

The returning hot condensate to the boiler has many several reasons. Using return process condensate to heat feed water less amount of make-up water is required, less oil is needed to produce steam from hot water rather than cold water. Return of high purity condensate i.e. distilled water reduces also chemicals and treatment cost as well as energy losses due to the boiler blowdown [8]. In analysed procedure the process condensate in amount of $d_{C R}=14,170 \mathrm{~kg}_{C} / \mathrm{kg}_{P}$ with temperature $t_{c}=121^{\circ} \mathrm{C}$ is returned and mixed with the make-up water in mass $d_{w}=0,700 \quad \mathrm{~kg}_{w} / \mathrm{kg}_{\mathrm{p}}$ with temperature $\mathrm{t}_{\mathrm{w}}=25^{\circ} \mathrm{C}$.

Considering the adiabatic mixing process, the feed water will enter the boiler with temperature:

$$
t_{m}=\left(d_{C R}\right.
$$

$\left.x t_{c}+d_{w} t_{w}\right) / d_{s}=(14,170 \times 121+0,700 \times 25) / 14,870=116,48^{\circ}$

C.

The oil consumption is after heat balance:

$$
\begin{gathered}
d_{F C}=d_{S}\left(h_{s}-h_{m}\right) / H_{L} \times n_{B}=14,870(2785- \\
492) 41268 \times 0,8=1,03 \text { kg }_{F} / k_{p} .
\end{gathered}
$$

The specific steam consumption is:

$$
d_{\mathrm{SPC}}=d_{\mathrm{s}} / \mathrm{d}_{\mathrm{FC}}=14,870 / 1,03=14,44 \mathrm{~kg}_{\mathrm{s}} / \mathrm{kg}_{\mathrm{P}} \text {. }
$$

Yearly consumption is:

$D_{F C Y}=d_{F} \times \times n=1,03 \times 2400 \times 625=1,545 \times 10^{6} \mathrm{~kg}_{F}$

Heat condensate for feed water preheating is:

$$
Q_{c}=d_{c} \times h_{121}{ }^{0}=14,170 \times 507=7184,19 \mathrm{~kJ}_{\mathrm{c}} / \mathrm{kg}_{\mathrm{p}} \text {. }
$$

The application of return condensate with process without condensate heat recovery shows oil savings of:

$$
S=\left(d_{F}-d_{F C}\right) / d_{F}=(1,21-1,03) / 1,21=0,1487 \text { i.e. } 14,9 \% \text {. }
$$

The condensate heat, which is discharged to the surrounding becomes:

$$
\mathrm{q}_{\mathrm{CH}}=\mathrm{d}_{\mathrm{CH}} \times \mathrm{h}_{121}=0,7 \times 507=354,9 \mathrm{~kJ}_{\mathrm{C}} / \mathrm{kg}_{\mathrm{P}} \text {. }
$$

So, the thermal pollution is decreased from 7539,1 $\mathrm{kJ}_{\mathrm{C}} / \mathrm{kg}_{\mathrm{p}}$ to $354,9 \mathrm{~kJ} / \mathrm{kg}_{\mathrm{p}}$ or for $95,3 \%$.

In this analyses case the flue gases volume per unit of product that is rejected to the atmosphere with temperature $t_{F G}=221^{\circ} \mathrm{C}$ is:

$$
V_{F G C}=V_{F G} \times d_{F C}=14,1455 \times 1,03=14,57 \mathrm{~m}^{3}{ }_{F G} / k_{P} \text {. }
$$

The volume of exhaust gases is lowered from 17,11 $\mathrm{m}_{\mathrm{FG}}^{3} / \mathrm{kg}_{\mathrm{P}}$ to $14,57 \mathrm{~m}_{\mathrm{FG}}^{3} / \mathrm{kg}_{\mathrm{P}}$ or for $14,8 \%$.

\subsection{FEED WATER PREHEATING WITH FLUE GASES}

Input data summary:

The economizer efficiency $\eta_{E}=80 \%$

The economizer water inlet temperate $\mathrm{t}_{\mathrm{WEi}}=116,78^{\circ} \mathrm{C}$ The volume of exhaust gases $\mathrm{V}_{\mathrm{FG}}=14,1455 \mathrm{~m}^{3}{ }_{\mathrm{FG}} / \mathrm{kg}_{\mathrm{F}}$ The economizer flue gases inlet temperate $t_{\mathrm{FGEi}}=221^{\circ} \mathrm{C}$ The specific steam consumption $d_{S P}=14,44 \mathrm{~kg}_{\mathrm{S}} / \mathrm{kg}_{\mathrm{F}}$ The specific heat of water $\mathrm{C}_{\mathrm{pH} 2 \mathrm{O}}=4,187 \mathrm{~kJ} / \mathrm{kg} \mathrm{K}$

The specific heat of flue gases $C_{p F G}=1,392 \mathrm{~kJ}_{\mathrm{FG}} / \mathrm{m}^{3} \mathrm{deg}$ The mass of dry saturated steam $d_{s}=14,870 \mathrm{~kg}_{\mathrm{s}} / \mathrm{kg}_{\mathrm{P}}$ The enthalpy of steam $h_{s}=2785 \mathrm{~kJ} / \mathrm{kg}$

The fuel lower heating value $H_{L}=41268 \mathrm{~kJ} / \mathrm{kg}_{F}$

Cold water with temperature $t_{\mathrm{wEi}}=116,78^{\circ} \mathrm{C}$ enters the economizer where is heated with flue gases in amount $\mathrm{V}_{\mathrm{FG}}=14,1455 \mathrm{~m}_{\mathrm{FG}}^{3} / \mathrm{kg}_{\mathrm{F}}$ and inlet temperature $t_{\mathrm{FGEi}}=221^{\circ} \mathrm{C}$. The specific steam consumption is $\mathrm{d}_{\mathrm{SP}}=14,44 \quad \mathrm{~kg}_{\mathrm{s}} / \mathrm{kg}_{\mathrm{F}}$. With specific heat of water $\mathrm{c}_{\mathrm{p}}$ ${ }_{\mathrm{H} 2 \mathrm{O}}=4,187 \mathrm{~kJ} / \mathrm{kg} \mathrm{K}$ and flue gases $\mathrm{C}_{\mathrm{p} \mathrm{FG}}=1,392 \mathrm{~kJ}_{\mathrm{FG}} / \mathrm{m}^{3}$ deg calculated previously.

The economizer water outlet temperate $\left(t_{W_{E_{0}}}\right)$ can be calculated from the energy balance equation:

$$
\begin{aligned}
& V_{F G *} c_{p F G *}\left(t_{F G E i}-t_{W E i}\right) * \eta_{E}=d_{S P *} c_{p H 2 O} *\left(t_{W E O}-t_{W_{E i}}\right) \\
& t_{W E O}=\left[V_{F G *} c_{p F G *}\left(t_{F G E i}-t_{W E i}\right) * \eta_{E}+d_{S P *} c_{p H 2 O} t_{W_{E E}}\right] \\
& \mathrm{d}_{\mathrm{SP} *} \times \mathrm{c}_{\mathrm{p} \mathrm{H} 2 \mathrm{O}} \\
& t_{\mathrm{WEo}}=143,71^{\circ} \mathrm{C}
\end{aligned}
$$

The economizer flue gases outlet temperate $\left(\mathrm{t}_{\mathrm{FG} \mathrm{Eo}}\right)$ can be calculated from the relation:

$$
\begin{aligned}
& V_{\mathrm{FG}} * c_{\mathrm{pFG}}\left(t_{\mathrm{FGEi}}-t_{\mathrm{FG} \mathrm{EO}}\right)=d_{\mathrm{SP} *} c_{\mathrm{pH} 2 \mathrm{O}} *\left(t_{\mathrm{WEO}}-t_{\mathrm{WEi}}\right) \\
& t_{F G E O}=\left[d_{S P *} c_{p H 2 O^{*}}\left(t_{W E O}-t_{W_{E i}}\right)-V_{F G *} c_{p F G *} t_{F G E I}\right] / V_{F G} \text { * } \\
& \mathrm{C}_{\mathrm{pFG}} \\
& t_{\mathrm{FGEo}}=137,39^{\circ} \mathrm{C}
\end{aligned}
$$


The fuel consumption is then calculated as:

$$
\begin{gathered}
d_{F E}=d_{s^{*}}\left(h_{s}-h_{W_{E}} / / n_{B} * H_{L}=14,870 *(2785-601,7) /\right. \\
0,8 * 41268=0,983 \mathrm{~kg}_{\mathrm{F}} / \mathrm{kg}_{\mathrm{P}} .
\end{gathered}
$$

where $h_{S}$ and $h_{\text {WEo }}$ are enthalpies of steam and water.

The comparison of process with and without flue gases heat recovery shows fuel savings of:

$$
\begin{gathered}
S_{1}=\left(d_{F}-d_{F E}\right) / d_{F}=(1,21-0,983) / 1,21=0,1876 \text { i.e. } \\
18,76 \% .
\end{gathered}
$$

The flue gases rejected to the atmosphere is now:

$$
V_{\mathrm{FGE}}=\mathrm{V}_{\mathrm{FG}}{ }^{*} \mathrm{~d}_{\mathrm{FE}}=14,1455 * 0,983=13,90 \mathrm{~m}^{3}{ }_{\mathrm{FG}} / \mathrm{kg}_{\mathrm{P}} \text {. }
$$

\section{CONCLUSIONS}

Calculating the energy savings in rubber processing plants is of great importance since the synthetic rubbers accounts for the majority of rubber production. Most of the shoe soles today are made from Ethylene Vinyl Acetate (EVA). This paper analyses the potential of energy savings using the process return condensate and feed water preheating using the flue gases heat recovery in EVA shoe soles production process. The energy savings are seen through lower make up water consumption, substantial fuel savings and lower chemical consumption. Returning hot process condensate to the boiler results in oil savings of $14,9 \%$, the thermal pollution is reduced by $95,3 \%$, while the volume of the flue gases is lowered from 17,11 $\mathrm{m}^{3} \mathrm{FG}_{\mathrm{F}} / \mathrm{kg}_{\mathrm{NEC}}$ to $14,57 \mathrm{~m}^{3} \mathrm{FG} / \mathrm{kg}_{\mathrm{NEC}}$ or by $14,8 \%$. Also, The implementation of flue gases heat recovery for feed water preheating can improve the technological process. By applying the presented method, the flue gases are cooled which causes increasing of feed water temperature.

\section{Acknowledgements}

This paper is funded by project HRZZ IP-06-2016 5278: Comfort and antimicrobial properties of textiles and footwear (ComforMicrobTexFoot).

\section{References}

[1] Landrock, Arthur H. 1995. Handbook of plastic foams types, properties, manufacture and applications. Noyes Publications.

[2] Groover, M. P. 2010. Fundamentals of Modern Manufacturing: Materials, Processes and Systems. $4^{\text {th }}$ edition, John Wiley \& Sons Inc.

[3] Karkalića, R. M.; Radulović, J. R.; Jovanović, D. B. 2017. Characteristics of polyurethane and elastomer parts for shoe industry produced by liquid injection molding technology. Vojnotehnički glasnik, vol. 65, br. 4, str. 948 967 http://dx.doi.org/10.5937/vojtehg65-10543.

[4] Chung, T. C. Mike. 2002. Functionalization of Polyolefins. $1^{\text {st }}$ edition, Academic Press.

[5] Brito e Dias, R.; Coto, N. P.; Batalha, G. F.; Driemeier, L. 2018. Systematic Study of Ethylene-Vinyl Acetate (EVA) in the Manufacturing of Protector Devices for the Orofacial
System, Chapter 14, Biomaterials in Regenerative Medicine, ISBN: 978-953-51-3777-1.

[6] Shi, X. M.; Zhang, J.; Jin, J.; Chen, S. J. 2008. Nonisothermal crystallization and melting of ethylene-vinyl acetate copolymers with different vinyl acetate contents. eXPRESS Polymer Letters Vol. 2, No. 9, 623 - 629, DOI: 10.3144/expresspolymlett.2008.75

[7] Jeng, Y. -R.; Liu D. -S. and Yau, H. -T. 2012. Designing Experimental Methods to Predict the Expansion Ratio of EVA Foam Material and Using Finite Element Simulation to Estimate the Shoe Expansion Shape. Materials Transactions, Vol. 53, No. 9, pp. 1685 to 1688.

[8] Nautiyal, O. H. 2012. Molding of EVA Soles Using Expanding and Reducing Agents. International Journal of Engineering Science and Technology (IJEST), Vol. 4 No. 07, pp. 3050 - 3058.

[9] López, L. C. 2014. Polymer injection moulding for shoe soles production. M. Sc. Thesis, Vilnius Gediminas technical university faculty of mechanics.

[10] Ferreir, E. J.; Dias, M. M.; Schneider, E. L. 2018. Analysis of Non-Uniform Expansion Behavior of Injected EVA. Academ J Polym Sci.; 1(4): 555569.

[11] Mihelić-Bogdanić, A.; Budin, R. 2008. Investigation on energy conservation in thermoplastics production, Energy conversion and management, 49, 8; 2200 -2206, doi:10.1016/j.enconman.01.028

[12] Eastop, T. D.; McConkey, A. 1994. Applied Thermodynamics for Engineering Technologists. $5^{\text {th }}$ ed. New York: Longman Scientific \& Technical, John Wiley \& Sons.

[13] Bošnjaković, F. 1971. Technische Thermodynamik. Dresden: Verlag T. Steinkopff.

[14] Wang, L.; Hong, Y.; Li, J. X. 2012. Durability of running shoes with ethylene vinyl acetate or polyurethane midsoles. Journal of Sports Sciences, 30, 16, 1787 1792, doi:10.1080/02640414.2012.723819

[15] Lopes, D.; Ferreira, M. J.; Russo, R.; Dias, J. M. 2015. Natural and synthetic rubber / waste - EVA (EthyleneVinyl Acetate) composites for sustainable application in the footwear industry. Journal of Cleaner Production, $\quad 92, \quad 230 \quad-\quad 236$, http://dx.doi.org/10.1016/j.jclepro.2014.12.063

[16] Fuss, F. K.; Subic, A.; Strangwood, M.; Mehta, R. 2014. Routledge Handbook of Sports Technology and Engineering. Routledge, Taylor and Francis, ISBN 9780415580458

[17] Špelić, I.; Mihelić-Bogdanić, A.; Budin, R. Energy savings in shoe sole production process. In: Book of Proceedings of the 12th International Scientific-Professional Symposium Textile Science and Economy, FrenchCroatian Forum, 23. do 24. siječnja 2019. Zagreb. Hrvatska, pp. $245-254$. 